\title{
LIMESTONE FILLERS CEMENT BASED COMPOSITES: EFFECTS OF BLAST FURNACE SLAGS ON FRESH AND HARDENED PROPERTIES
}

\author{
Luc COURARD ${ }^{1}$ and Frédéric MICHEL \\ University of Liege, ArGEnCo Department, GeMMe Building Materials, Belgium
}

\begin{abstract}
Limestone filler is a raw material that is already used in several applications like paints, bricks, bituminous mixtures...etc. Moreover, and particularly in Belgium, classical additions for concrete like fly ashes and granulated blast furnace slags are becoming rare; there is a need for new additions that could have a positive effect on the properties of the fresh and hardened cementitous composites.

Substitution of limestone filler in Portland cement and Granulated blast furnace slag cement has been realized between 15 and $27 \%$ in mass. In addition to the characterization of the powder itself - specific mass, specific surface and laser granulometry - the problem of the water demand has been analysed: it seems that it remains constant with the substitution rate. Electric conductivity has also been performed in order to study the evolution of the "dormant" period. Tests on hardened mortars were performed with regard to mechanical properties and evolution of the porosity. Test results indicate that the porosity seems to be finer in the case of granulated blast furnace slags cements, partially due to a very low diameter of the slags particles. Oxygen permeability doesn't seem to be influenced by the filler while capillary absorption increases with substitution rate. Finally, carbonation rate, sulphate resistance and chloride penetration show quite interesting behaviours, leading to the conclusion that limestone fillers maybe a good substitution material.
\end{abstract}

Keywords: limestone, filler, substitution, cement, granulated blast furnace slags, mortar, water demand, porosity, oxygen permeability, capillary suction, carbonation, chloride ingress, sulphate attack.

\footnotetext{
${ }^{1}$ Corresponding author : Luc.Courard@ulg.ac.be Université de Liège, Département ArGEnCo, Chemin des Chevreuils, 1 - 4000 LIEGE (Belgique) Tél : 32.4.366.93.50 - Fax : 32.4.366.95.20
} 


\section{INTRODUCTION}

Common additions such as fly ashes and granulated blast furnace slags are widely used in Belgian cement industry. On the other hand, limestone fillers are quite abundant and already used in several applications [1]: they are actually cheaper and more "sustainable" than cement. This is the reason why limestone fillers for cement substitution were investigated, specifically for Self Compacting Repair Mortars [2] but also classical Self Compacting Concrete (SCC) [3].

Mineral filler are usually defined as an "inert material that is included in a composition for some useful purpose" [4]. It can be added to compounds to fulfil a large variety of final results or to improve specific characteristics like hardness, brittleness, impact strength, compressive strength, softening point, fire resistance, surface texture, electrical conductivity, ... etc $[5,6]$. These effects are the result of the properties of the fillers, including chemical activity, hardness, particle size, shape and distribution, surface structure, colour, density and refractive index $[7,8]$.

Limestone fillers are notably used as cement replacement materials (cement additions); they are well-adapted, specifically for Belgian market, because of their local availability [9]. As the behaviour of fresh and hardened concrete depends on the intrinsic properties of fines [10], the use of these by-products requires a thorough characterization [11]. Rheological problems may be solved usually by means of admixtures and viscosity agents [12].

Durability of limestone cement based mixtures has been studied, specifically for Self Compacting Concrete [13, 14]. Results don't show clear impact of limestone fillers on carbonation depth even if SCC generally presents an improved behaviour with regard to ordinary concrete [15]. Resistance to chloride diffusion and freeze-thaw cycles are mainly dependent on pore size distribution and connectivity of pores: as limestone fillers may partially fulfil capillary pores, some improvement is expected [16].

This research project tends to quantify limestone fillers effects on the durability of limestone fillers cement based composites.

\section{EXPERIMENTAL PROGRAM}

\subsection{Tests for Durability}

Three levels of investigations have been selected: fine material, slurries and mortars. The characterization of fine materials is based on sieving and specific surface [7]. The modified cement paste was also analysed with regards to its water demand and its electric conductivity: these results gave us information about fresh behaviour and hydration process. Afterwards, tests were carried out on fresh and hardened mortar in order to determine consistency [17], mechanical characteristics [18], shrinkage [19], porosity [20], capillary absorption [21] and permeability to oxygen [22]. Durability of mortars was finally evaluated through their resistance to carbonation [23], sulphates and chloride ingress [24]. 
The strength activity indexes at 28 days, determined in accordance with French standard NF P18-508 [25], have been evaluated: strength activity index is defined as the ratio between compressive strength measured at the same age on specimens prepared with $75 \%$ reference cement and $25 \%$ limestone filler, by mass, and $100 \%$ reference cement, respectively.

\subsection{Materials}

Two cements (Portland cement and granulated blast furnace slag cement) and four rates of substitution $(0,15,23$ and $27 \%$ by mass) of limestone filler were tested, i.e. eight mixtures: these very high limestone filler contents were selected in order to promote concrete with lower $\mathrm{CO}_{2}$ footprint. A normalized sand (EN 196-1) and water tap were used. The Portland cement was of CEM I 42.5 R HES type: this is a $100 \%$ Portland clinker which is characterized by a high early strength (www.holcim.be). Binary cement was artificially but precisely composed with $65 \%$ (by mass) of Portland cement and $35 \%$ of Granulated Blast Furnace Slag (bfs) directly obtained from producer. The filler comes from a local limestone quarry [26].

Table 1 shows the mineralogical composition, the specific mass and the specific surface of the three powders used for composing the binders. Particle Size Distributions (PSD) of blast furnace slags (bfs), limestone filler and cement were performed by means of laser diffraction while specific surface area was measured according to Blaine method [7, 26]. The characteristic percentile diameters $\mathrm{d}_{50}$ is reported. Fig. 1 shows that Granulated Blast furnace Slags (bfs) offer the finer particle but a less continuing gradation. Limestone fillers are fine products but coarser with $\mathrm{d}_{50}=12.60 \mu \mathrm{m}$. The cement is well graded with the smallest amount of fine particles (around $27 \%$ of particles smaller than $5 \mu \mathrm{m}$ ). Blaine specific surface areas are ranging from about 2,700 to $3,090 \mathrm{~m}^{2} / \mathrm{kg}$; the highest value is obtained for cement particles.

Recent studies [27, 28] have shown that limestone filler particles (LF) have a lower bluntness in comparison with cement grains. This may be due to longer crushing process for limestone (from meter level) than for clinker (from centimeter level). Blending cement with fillers can effectively improve the packing density of the binder (Fig. 2). Dry packing methods are conventionally performed according to standard code BS 812-2 [29]; in this case, conventional dry packing method has been modified by introducing vibration and compaction in order to reduce the influence of inter-particle forces [28]. The higher amount of limestone fillers in mixes can result in a higher packing density of solid particles, which is favourable for durability and strength behaviour.

\subsection{Mortar compositions}


The different compositions are characterized by the same sand and water contents. Water demand and consistency tests showed indeed that these two properties remained constant whether limestone filler was incorporated or not. It was then decided to work with a constant water-to-binder ratio of 0.45 (by mass) for all the mixtures. Four substitution rates were tested with the two cements $(0,15,23$ and $27 \%$ by mass). Table 2 presents the eight compositions tested, as well as air content (EN 1015-7) [30].

Mortars are referred by M-P when cement is $100 \%$ Portland cement and M-BFS when cement is composed of 65\% Portland cement and 35\% Blast Furnace Slags. Mortars were prepared in accordance with European Standard EN 196-1 [18]. Water was first introduced in the mechanical blender. The dry mix solids (cement + filler) were then added to the water solution and mixed for 30 seconds at low speed; sand was added and mixed for 30 seconds. Then the mixing proceeds in a sequence of three steps: 30 seconds mix at high speed, 90 seconds in rest, 60 seconds mix at high speed. After casting, the samples were covered with wet burlap and a polyethylene sheet for $24 \mathrm{~h}$. They were then stored for 27 days at $(20 \pm 2){ }^{\circ} \mathrm{C}$ and $(90 \pm 10) \%$ R.H.

\section{RESULTS AND DISCUSSIONS}

\subsection{Tests on cement paste and fresh mortars}

\subsubsection{Evaluation of water demand}

The water demand (Fig. 3) is characterized by the $\beta$ p factor (expressed by mass) [31]. Beta $P$ tests $[26,32]$ are performed in order to quantify water demand $\beta_{p}$ of the mixture corresponding to a paste without spreading. The test involves the measure of the spreading of a paste for different water contents and the determination of a factor $\mathrm{R}$ from the spreading diameter $\mathrm{D}(\mathrm{mm})$, according to (eq.1):

$$
R=\left(\frac{D}{100}\right)^{2}-1
$$

Then, by extrapolation of the experimental points to abscissa zero using linear regression (Fig. 3), the water demand $\beta_{\mathrm{p}}$ is determined.

The $\beta_{\mathrm{p}}$ factor takes into account the water adsorbed on the surface of the powder and the water needed to fill the gaps, in order to provide lubrication particles just below that which would making them moving.

The $\beta_{\mathrm{p}}$ factor varies (Fig. 4) from 0.31 to 0.35 for all the mixtures tested. There is not a significant variation whatever the filler content and the type of cement: we can conclude that 
the water demand remains constant when substitution of cement by limestone filler, with or without granulated blast furnace slags.

\subsubsection{Setting time and conductivity}

The conductivity of solutions is measured by applying a voltage between two electrodes in a conductivity cell [7]. At any time, anions are migrating to the positive electrode and cations to the negative one. The conductivity of solutions $(\mathrm{mS} / \mathrm{cm})$ is the conductance which would be measured in a standard cell containing two ring electrodes held $3 \mathrm{~cm}$ form each other. The conductivity of a dilute solution is the sum of the individual contributions to conductivity of all the ions multiplied by their concentration, as conductivity is indeed directly proportional to concentration. The statement is that each ion contributes to the total conductivity without being affected by any other ion in solution (Eq. 2):

$$
\kappa=\frac{\sum \lambda_{i}{ }_{i} \cdot c_{i}}{1000}
$$

where $\kappa$ is the measured conductivity $(\mathrm{mS} / \mathrm{cm}), c_{i}$ is the concentration of the ions (equivalents/l) and $\lambda_{\mathrm{i}}^{\circ}$ is the ionic limiting equivalent conductivity (Table 3 ), which is specific for each ion. The Conductivity Meter CDM 210 we used is able to measure initial and maximal conductivity values and duration of the dormant period.

Deionized water has been used to prepare the samples at constant temperature $(25 \pm 1)^{\circ} \mathrm{C}$. All the samples used for conductivity test were prepared in the same way:

- mix of cement, water (limestone filler and blast furnace slag) for 3 minutes at high speed;

- fulfilling of the conductivity cells with slurries;

- registration of the temperature all along the test.

Because it is dependent on the ions dissolved in the solution [33, 34], the measurement of the evolution of the electric conductivity over time can give information about the hydration process. The "dormant" period is representative of the setting time: at the end of this period, the setting really begins.

As shown on Fig. 5, the "dormant" period is shorter for the M-BFS mixtures containing limestone fillers: this phenomenon was already observed and explained through the fact that carboaluminates are growing and accelerating the setting by nucleation action [33]. We can also observe that the duration of the "dormant" period is longer for the M-BFS mixtures than for the M-P mixtures: this is due to the latent characteristic of the granulated blast furnace slag. 
The setting and hardening times have been measured in accordance with EN 197-1. The setting time (Ti) results (Fig. 6) clearly indicate a short delay when using Granulated Blast Furnace Slag (M-BFS) in comparison with Portland cement (M-P): the use of limestone fillers seems to increase the setting time of M-GBS mixes but has almost no impact for hardening time. Limestone fillers do not modify the behaviour of M-P mixes. As for the setting time, hardening time (Tf) is longer for M-BFS samples than M-P samples.

\subsubsection{Workability of fresh mortar}

The workability of mortars was evaluated according to slump test [17]: final diameter of the slump is divided by the initial diameter of the mortar cone, which expresses workability (Fig. 7). The results obviously show that workability remains constant, irrespective of the mixtures and limestone filler content, which is in accordance with water demand evaluation [29].

\subsection{Properties of hardened mortar}

3.2.1. Mechanical and shrinkage properties

According to the literature [5, 10], limestone fillers improve the transition zone between aggregates and cement paste and reduce its thickness. This may have a positive effect on compactness of the hydrated mix. However, the compressive strength decreases when cement is replaced by limestone filler (Fig. 8). This is due to the decrease of the cement content and the rising of the water-to-cement ratio, as substitution increases. Figure 8 also shows the wellknown difference between the two cements tested: granulated blast furnace slag cement presents a lower strength at early age (19\% decrease) but a higher strength at 28 days (9\% increase) than the Portland cement.

The $\mathrm{i}$ factor (or activity index) can be calculated as the ratio of the compressive strength of a mortar where $25 \%$ (by mass) of cement are replaced by limestone filler and with a water-tobinder ratio of 0.5 , and the compressive strength of a normalized mortar [5]. The i factor of the filler is 0.70 when Portland cement is used and 0.76 when the granulated blast furnace slag cement is used. For a water-to-cement ratio of 0.5 , the loss of strength at 28 days is greater for the Portland cement (M-P) than for the granulated blast furnace slag cement (MBFS) when $25 \%$ of the cement is substituted by limestone filler.

Total shrinkage was measured on specimens stored at $20{ }^{\circ} \mathrm{C}$ and $65 \% \mathrm{HR}$ : shrinkage decreases as the substitution rate increases (Fig. 9). This is due to the decrease of the cement content and raise of the water-to-cement ratio as the substitution rate increases (considering that the cement content decreases when cement is substituted by limestone filler). 
Portland cement mixture presents larger shrinkage than granulated blast furnace slag cement mixtures (Fig. 9): M-BFS mixtures probably do not probably attract water at the same rate due to less reactive materials, which may induce less chemical shrinkage.

The autogenous shrinkage was measured on specimens that have been coated by aluminium foil and epoxy paint (Fig. 9). The autogenous shrinkage generally decreases as the substitution rises. This is also due once again to the lower cement content and the higher water-to-cement ratio, which keeps a high internal humidity and induces a lower chemical shrinkage: this was already observed by Craeye et al. [36].

\subsubsection{Porosity and permeability of mortars}

The "open" porosity was determined by a water absorption test [20]. Water absorption is growing between 0 and $15 \%$ substitution of cement by limestone filler (Fig. 10); above 15\%, it doesn't seem to evolve. Compositions containing granulated blast furnace slags show a lower "open" porosity; which is probably due to the fineness of the granulated blast furnace slag particles and the more dense microstructure generated by lower $\mathrm{Ca}(\mathrm{OH})_{2}$ content.

In order to determine permeability to oxygen, a cylindrical specimen is drilled, dried at $60^{\circ} \mathrm{C}$ until constant mass and laterally covered with epoxy resin before introduction into the permeability test device. A pressure is imposed at the bottom of the sample and permeability to oxygen is determined from the oxygen flow measured at the top side [22]. The results show that oxygen permeability remains constant for all the mixtures: the limestone filler doesn't seem to have any influence (Table 4); however, M-BFS seem to offer lower permeability than M-P samples. This property depends on the interconnected pores but cannot directly be correlated to the "open" porosity described here above, as molecules of oxygen have smaller dimensions than those of water.

The capillary absorption [21] is characterized by the sorption coefficient (the slope of the line representing water absorption by surface unit as a function of the square root of the immersion time). The sorption coefficient increases with the substitution rate (Fig.11) but lower when M-BFS samples at $15 \%$ substitution. This sorption is directly related to the dimensions of the pore [37, 38]: larger pores are sucking more water when sample comes into contact with water. Once again, finer material (BFS) will induce smaller pores and lower sorption coefficient.

\subsubsection{Transfer and durability properties}

$\mathrm{CO}_{2}$ penetration and chloride diffusion give useful data on durability of cementitious mixtures. These properties depend on the open porosity that permits or not the intrusion of aggressive agents. Transport mechanism of ions or molecules is ruled by diffusion: the aggressive agent is moving according to a difference of concentration. 
Carbonation, which results from the chemical reaction between lime and carbon dioxide, induces a decrease of the $\mathrm{pH}$ of the interstitial solution of concrete and influences steel corrosion. The carbonation depth is determined by means of phenolphthalein test [23]. Figure 12 shows the carbonation depth of the compositions tested after 3 months of exposure to $\mathrm{CO}_{2}$ ( $1 \%$ concentration and $60 \%$ R.H.): the carbonation depth increases as the filler content rises. This result may be correlated to the "open" porosity: when it increases, the molecules of $\mathrm{CO}_{2}$ may easier penetrate into the mortar. On the other hand, diffusion rate depends on the reactive product concentration inside the mortar: less $\mathrm{Ca}(\mathrm{OH})_{2}$, as it is for granulated blast furnace slag mixtures, will induce a higher diffusion rate [39]. Finally, carbonation depth is very similar for the two types of cements and limestone fillers consequently induce a decrease of resistance to $\mathrm{CO}_{2}$ penetration [15].

Moreover, diffusion rates of $\mathrm{Cl}^{-}$and $\mathrm{Na}^{+}$ions into cement mortars were monitored using two compartment diffusion cells (Fig. 13). Mortar blocks $10 \mathrm{~mm}$ thick are sawed from $8 \mathrm{~cm}$ diameter specimens and stored into $\mathrm{Ca}(\mathrm{OH})_{2}$ saturated solution. Prior to the test, each specimen is polished with 600-grade emery paper, rinsed with de-ionized water and surface dried with a tissue before being fitted into the diffusion cell. After fitting with epoxy resin and sealing with silicon paste, the cells are filled at one side with $\mathrm{Ca}(\mathrm{OH})_{2}$ solution and at the other side with $3 \mathrm{M} \mathrm{NaCl}$ in saturated $\mathrm{Ca}(\mathrm{OH})_{2}$ solution. At periodic intervals, chloride concentration is determined by titration from a $10 \mathrm{~mm}^{3}$ sample of the solution.

The chloride penetration is determined by two characteristics: the evolution of the chloride content in the first cell, where there was no chloride ions at the beginning of the test, and the occurrence time (breakthrough time), which is calculated from the intercept of the concentration versus time date [24]. This corresponds to the time that is necessary to detect the first chloride ion in the first cell.

When limestone filler is added to cement (M-P), the chloride content in the first cell after 70 days increases and the occurrence time decreases (Fig. 14). This may be related once again to the "open" porosity as for the carbonation rate. The M-BFS mixtures however don't seem to allow the chloride ions crossing the mortar slice, at least after 100 days test: in this case, diffusion rate doesn't depend anymore on $\mathrm{Ca}(\mathrm{OH})_{2}$ concentration but only on connected porosity.

\subsubsection{Sulphate attack}

Analysis of the resistance of mortars to sulphates is performed according to standard NF P 18837 [35]. The method involves the determination of the changes in length of prismatic specimens when stored in a standard sulphate solution. When 28 days old, the specimens are measured for length and stored into sulphate solution with a concentration of $50 \mathrm{~g} /$ litre $\mathrm{SO}_{4}=$ and prepared by adding reagent grade magnesium sulphate $\left(\mathrm{SO}_{4} \mathrm{Mg} .7 \mathrm{H}_{2} \mathrm{O}\right)$ to water. 
Corresponding control specimens are stored into de-ionized water. Changes in length of the specimens are measured after storage periods of 1,2 and 3 months at $20 \pm 2{ }^{\circ} \mathrm{C}$, respectively. Cement paste can react with sulphates and form secondary ettringite which makes the concrete disintegrate. The deformation is monthly measured.

The resistance to sulphates of M-BFS mixtures (Fig. 15) doesn't seem to be influenced by limestone fillers: the granulated blast furnace slag cements are already well known to be sulphate resistant by them as it contains lower quantity of $\mathrm{C}_{3} \mathrm{~A}$. Mixtures with high substitution rates of clinker by limestone fillers and blast furnaces slags dramatically dilute the potential effect of expanse reactive materials. Portland cement mixtures however present a more sensitive behaviour, which seems to be influenced by limestone filler, especially for substitution rate of $15 \%$. Higher limestone content doesn't seem to be so tremendous, which means there is potentially a "pessimum" limestone content, similarly to what happens for alkali aggregate reactions.

\section{CONCLUSIONS}

Some effects of limestone filler and blast furnace slags as a partial substitute for cement in cement based composites were analysed. We can draw the following conclusions from the present results:

- the "dormant" period (i.e. the setting time) of the M-BFS mixtures decreases as the limestone filler substitution rate increases: this may be due to the formation of carboaluminates. The duration of the "dormant" period is longer for the M-BFS mixtures than for the M-P mixtures, which is probably due to the latent hydraulicity of the granulated blast furnace slag;

- evaluation the compressive strength and the total shrinkage decrease with the substitution rate, as a consequence of the cement content decrease. Autogenous shrinkage also decreases as the substitution rate rises;

- the $\mathrm{i}$ factor of the filler is 0.70 when Portland cement is used and 0.76 when the granulated blast furnace slag cement is used;

- the open porosity to water increases between 0 and $15 \%$ of substitution and remains constant between 15 and $27 \%$;

- mixtures containing granulated blast furnace slags show a lower "open" porosity; which is probably due to the fineness of the granulated blast furnace slag particles;

- the permeability to oxygen remain constant, with the limestone filler substitution rate and the type of cement;

- the capillary sorption coefficient increases with the substitution rate;

- the durability generally decreases when limestone filler is used: carbonation rate, chloride penetration and deformation due to sulphates increase as the substitution rises. 
The physical properties of materials (fineness, granulometry) have definitively influence of mixes behaviour, specifically water demand and workability).

Results clearly show that there is a modification of the microstructure: if substitution rate is too high, there will be an opening of the microstructure, especially when Portland cement is used. Granulated blast furnace slags tend to moderate this tendency, for similar or lower fineness of the particles: in this particular case, mixtures with granulated blast furnace slags (35\%) and limestone fillers (until 15\%) seem to offer a promising behaviour. More investigations are of course needed, particularly in terms of microscopic evaluation. It seems however that limestone filler can have an impact - positive or negative - on the behaviour of mortars and cannot be definitively considered as "inert" material.

Finally, these conclusions are of course available for test conditions described here above and for the materials that have been tested. Other types of fillers (mineral and chemical compositions) or granulated blast furnace slags could induce other behaviours and effects on mechanical and durability properties: initial properties of powder materials remain essential for obtaining interesting properties for mortars and concretes.

\section{ACKNOWLEDGEMENTS}

Support to this research project was provided by the Belgium (Wallonia Brussels International) and Quebec governments through the Scientific Cooperation Program 20112013: Sustainable Cementitious Materials with high Mineral Addition Contents.

\section{REFERENCES}

1. Ho DWS, Sheinn AMM, Ng CC,,Tam CT. The use of quarry dust for SCC applications. Cem Concr Res2002; 32: 505-11.

2. Flamant St, Courard L. Design of a Self Compacting Repair Mortar to be applied under concrete slabs and floors. In: Marchand, Bissonnette, Gagné, Jolin and Paradis eds. $2^{\text {nd }}$ RILEM Symposium Advances in Concrete through Science and Engineering (ed., Rilem Publications sarl, Paris), Québec, Canada: 2006.

3. Okamura H. Self-Compacting High-Performance Concrete, Con Int 1997; 19(7): 5054.

4. Severinghaus N. Fillers, filters and Absorbents in Industrial Minerals and Rocks. $5^{\text {th }}$ edition (ed. S.J. Lefond. American Institute of Mining, Metallurgical and Petroleum Engineers, Inc., New York) 1983: 243-257.

5. Courard L, Degeimbre R, Darimont A, Michel F, Willem X, Flamant St. Some effects of limestone fillers as a partial substitute for cement in mortar composition. In: ConMat'05 Third International Conference on construction materials: performance, 
innovations and structural implications (ed. N. Banthia). Vancouver, Canada, (August 22-24, 2005), Theme 3 - Chapter 5, 10p.

6. Meerseman J, Descamps P, Lucion C, Piérard J and Pollet V. Caractérisation des fillers calcaires wallons en vue de leur valorisation. Ciments, Bétons, Plâtres, Chaux (CBPC) 2006 ; $882: 29-36$ (in French).

7. Michel F. Physical characterization of limestone fillers. Master Thesis. Faculté des Sciences Appliquées, Université de liège, Belgium 2006: 204p (in French).

8. Michel F, Courard L. Particle size distribution of limestone fillers: granulometry and morphometry investigations. J Particulate Sc Tech (sent for publication).

9. Michel F, Piérard J, Courard L, Pollet V. Influence of physico-chemical characteristics of limestone fillers on fresh and hardened mortar performances. In: $5^{\text {th }}$ International RILEM Symposium on Self-Compacting Concrete, Proceedings PRO 54 (Eds. G. De Schutter and V. Boel, Rilem Publications), Gent, Belgium 2007: 205-210.

10. Gallias JL, Kara-Ali R, Bigas JP. The effect of fine mineral admixtures on water requirement of cement pastes. Cem Concr Res 2000; 30: 1543-9.

11. Michel F, Piérard J, Courard L. Application du concept de performance équivalente aux bétons additionnés de fillers calcaires. Annales du Bâtiment et des Travaux Publics 2008;3: 6-10.

12. Ferraris CF, Obla KH, Hill R. The influence of mineral admixture on the rheology of cement paste and concrete. Cem Concr Res 2001; 31(2): 245-55.

13. Audenaert K, De Schutter G. Chloride penetration by cyclic immersion of selfcompacting concrete. In: $5^{\text {th }}$ International RILEM Symposium on Self-Compacting Concrete, Proceedings PRO 54 (Eds. G. De Schutter and V. Boel, Rilem Publications), Gent, Belgium 2007: 695-700.

14. Boël V and De Schutter G. Freeze/thaw resistance of SCC in combination with deicing salts. In: $5^{\text {th }}$ International RILEM Symposium on Self-Compacting Concrete, Proceedings PRO 54 (Eds. G. De Schutter and V. Boel, Rilem Publications), Gent, Belgium 2007: 817-22.

15. Agnastopoulos N, Georgiadis S, Sideris K. Carbonation of self compacting concretes produced with different materials. In: $5^{\text {th }}$ International RILEM Symposium on SelfCompacting Concrete, Proceedings PRO 54 (Eds. G. De Schutter and V. Boel, Rilem Publications), Gent, Belgium 2007: 721-728.

16. Loser R, Leeman A. Chloride resistance of conventional vibrated and self-compacting concrete. In: $5^{\text {th }}$ International RILEM Symposium on Self-Compacting Concrete, Proceedings PRO 54 (Eds. G. De Schutter and V. Boel, Rilem Publications), Gent, Belgium 2007: 747-752.

17. EN 1015-3 (1999) Methods of test for mortars for masonry - Part 3: Determination of consistency of fresh mortar, CEN, Brussels.

18. EN 196-1 (1994) Method of testing cement: determination of strength.

19. NBN B14-217 (1970) Tests on mortars: shrinkage and swelling, Belgian Institute for Standardization, Brussels. 
20. NBN B15-215 (1969) Tests on concrete: water absorption by immersion, Belgian Institute for Standardization, Brussels.

21. EN 13057 (2002) Products and systems for the protection and repair of concrete structures - Test methods - Determination of resistance to capillary absorption, CEN, Brussels.

22. Lansival V. Air and oxygen permeability of concrete. Master Thesis. Faculté des Sciences Appliquées, Université de liège, Belgium 2000: 46-58 (in French).

23. EN 13295 (2000) Products and systems for the protection and repair of concrete structures - Test methods - Determination of resistance to carbonation, CEN, Brussels.

24. Courard L, Darimont A, Schouterden M, Ferauche F, Willem X, Degeimbre R. Durability of Mortars modified with metakaolin. Cem Concr Res 2003; 33(9): 1473-9.

25. NF P 18-508 (1995) Additions for hydraulic concretes - Limestone fillers Specifications and conformity, Paris, France.

26. Courard L, Michel F, Piérard J. Influence of clay in limestone fillers for selfcompacting cement based composites. Const Bldg Mat 2011; 25: 1356-61.

27. Courard L, He H. Physical and chemical characteristics of natural limestone fillers: mix properties and packing density. RILEM TC-SCM Workshop "Hydration and microstructure of concrete with supplementary cementitious materials", Limassol, Cyprus, 29-30 March 2012.

28. He H, Courard L, Pirard E. Particle Packing Density and Limestone Fillers for More Sustainable Cement. Key Engineering Materials 2012; 517: 331-7.

29. BS 812-2 (1995) Testing aggregates - Methods for determination of physical properties, London, UK.

30. EN 1015-7 (1999) Methods of test for mortar for masonry - Determination of air content of fresh mortar, CEN, Brussels.

31. Warland $\mathrm{Ch}$. Influence of granulometry of limestone fillers on water demand. Master Thesis. Faculté des Sciences Appliquées, Université de liège, Belgium 2005: 102p (in French).

32. Domone P, Chai HW. Testing of binders for high performance concrete. Cem Concr Res 1997; 27:1141-7.

33. Courard L, Michel F, Perkowicz S, Garbacz A. Effects of limestone fillers on the properties of the interstitial solutions of cement mixtures. Cem Concr Comp (in press).

34. Voglis N, Kakali G, Chaniotakis E, Tsivilis S. Portland-limestone cements. Their properties and hydration compared to those of other composite cements. Cem Concr Comp 2005; 27(2): 191-6.

35. NF P 18-837 (1993) Special products for hydraulic concrete constructions - Test for resistance against seawater and sulphate attack, Paris, France.

36. Craeye B, De Schutter G, Desmet B, Vantomme J, Heirman G, Vandewalle L, Cizer O, Aggoun S., Kadri EH. Effect of mineral type on autogenous shrinkage of selfcompacting concrete. Cem Concr Res 2010; 40: 908-13. 
37. Courard L, Degeimbre R. A capillary suction test for a better knowledge of adhesion process in repair technology. Can J Civil Eng 2003; 30(6): 1101-10.

38. De Schutter G., Audenaert K. Evaluation of water absorption of concrete as a measure for resistance against carbonation and chloride migration. Mater Struct 2004; 37: 5916.

39. Liang MT, Qu W, Liang CH. Mathematical modelling and prediction method of concrete carbonation and its applications. Journal of Marine Science and Technology 2002;10(2):128-135. 
Table 1 Chemical composition and physical characteristics of materials.

\begin{tabular}{lccc}
\hline & Portland cement & $\begin{array}{c}\text { Granulated Blast } \\
\text { Furnace Slag (bfs) }\end{array}$ & Limestone filler \\
\hline $\mathrm{CaO}$ & 62.8 & 38.46 & $98.1\left(\mathrm{CaCO}_{3}\right)$ \\
$\mathrm{SiO}_{2}$ & 19.3 & 35.08 & 0.533 \\
$\mathrm{Al}_{2} \mathrm{O}_{3}$ & 5.1 & 13.47 & 0.166 \\
$\mathrm{Fe}_{2} \mathrm{O}_{3}$ & 3.1 & 0.51 & 0.082 \\
$\mathrm{MgO}$ & 0.8 & 8.5 & 0.35 \\
$\mathrm{SO}_{3}$ & 3.1 & 0.1 & 0.085 \\
\hline Specific mass $\left(\mathrm{kg} / \mathrm{m}^{3}\right)$ & 3,090 & 2,890 & 2,700 \\
Specific surface $\left(\mathrm{m}^{2} / \mathrm{kg}\right)$ & 385 & 440 & 305 \\
\hline
\end{tabular}

Table 2 Mortar compositions

\begin{tabular}{ccccccccc}
\hline $\begin{array}{c}\text { Type of } \\
\text { cement }\end{array}$ & \% filler & $\begin{array}{c}\text { Mix } \\
\text { ref. }\end{array}$ & $\begin{array}{c}\text { Portland } \\
\text { Cement } \\
\left(\mathrm{kg} / \mathrm{m}^{3}\right)\end{array}$ & $\begin{array}{c}\mathrm{Bfs} \\
\left(\mathrm{kg} / \mathrm{m}^{3}\right)\end{array}$ & $\begin{array}{c}\text { Filler } \\
\left(\mathrm{kg} / \mathrm{m}^{3}\right)\end{array}$ & $\begin{array}{c}\text { Sand } \\
\left(\mathrm{kg} / \mathrm{m}^{3}\right)\end{array}$ & $\begin{array}{c}\text { Water } \\
\left(\mathrm{kg} / \mathrm{m}^{3}\right)\end{array}$ & $\begin{array}{c}\text { Air } \\
(\%)\end{array}$ \\
\hline Portland & 0 & M-P0 & 504 & 0 & 0 & 1513 & 227 & 3.86 \\
$(\mathrm{P})$ & 15 & M-P15 & 429 & 0 & 76 & 1518 & 228 & 3.23 \\
& 23 & M-P23 & 390 & 0 & 114 & 1512 & 227 & 3.40 \\
\hline Granulated & 0 & M-BFS0 & 329 & 177 & 0 & 1519 & 228 & 3.13 \\
blast furnace & 15 & M-BFS15 & 277 & 149 & 76 & 1510 & 227 & 3.38 \\
slag cement & 23 & M-BFS23 & 253 & 137 & 114 & 1512 & 227 & 3.08 \\
(BFS) & 27 & M-BFS27 & 238 & 128 & 138 & 1514 & 227 & 2.91 \\
\hline
\end{tabular}

Table 3 Values of $\lambda_{i}^{\circ}$ for some inorganic ions $\left[\frac{\mathrm{S} \cdot \mathrm{cm}^{2}}{\text { equiv. }}\right]$.

\begin{tabular}{cccc}
\hline Anions & $\lambda_{\mathbf{i}}^{\circ}$ & Cations & $\lambda_{\mathbf{i}}^{\circ}$ \\
\hline $\mathrm{OH}^{-}$ & 198 & $\mathrm{H}^{+}$ & 350 \\
$\mathrm{Cl}^{-}$ & 76 & $\mathrm{Na}^{+}$ & 50 \\
$\mathrm{SO}_{4}{ }^{2-}$ & 80 & $\mathrm{~K}^{+}$ & 74 \\
& & $\mathrm{Ca}^{2+}$ & 60 \\
\hline
\end{tabular}

Table 4 Air permeability $\left(\mathrm{k}_{\text {int }}\left(10^{-17} \mathrm{~m} / \mathrm{s}\right)\right)$ results for M-P and M-BFS samples 


\begin{tabular}{lllll}
\hline & \multicolumn{3}{c}{ Filler content $(\%)$} \\
Sample type & 0 & 15 & 23 & 27 \\
\cline { 2 - 5 } M-P & 1.68 & 2.12 & 2.47 & 2.28 \\
M-BFS & 1.56 & 0.91 & 1.07 & 1.22 \\
\hline
\end{tabular}




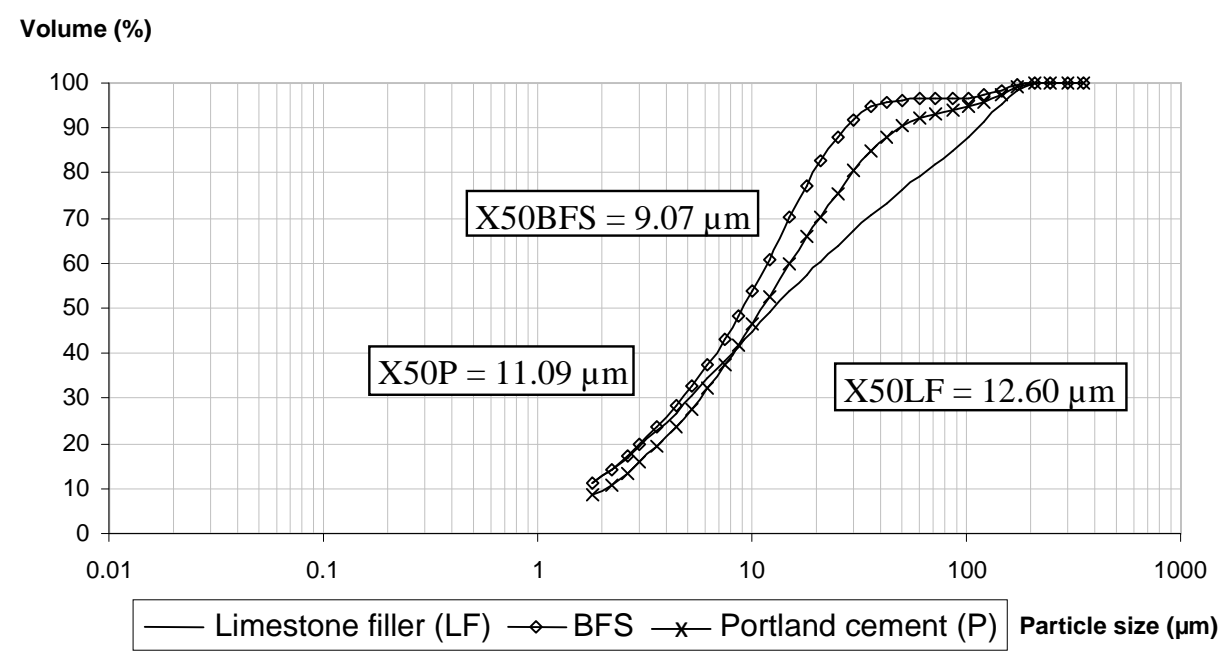

Figure 1: Particle size distribution of Portland cement $(\mathrm{P})$, granulated blast furnace slag (BFS) and limestone filler (LF)

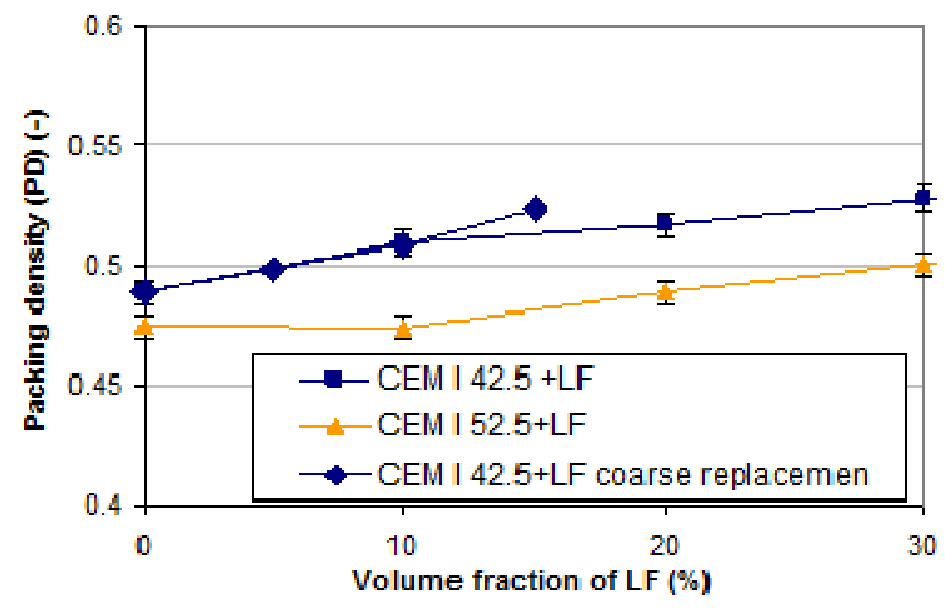

Figure 2: Dry packing density of limestone filler blended cement (error bars indicate the variance for three tests) 


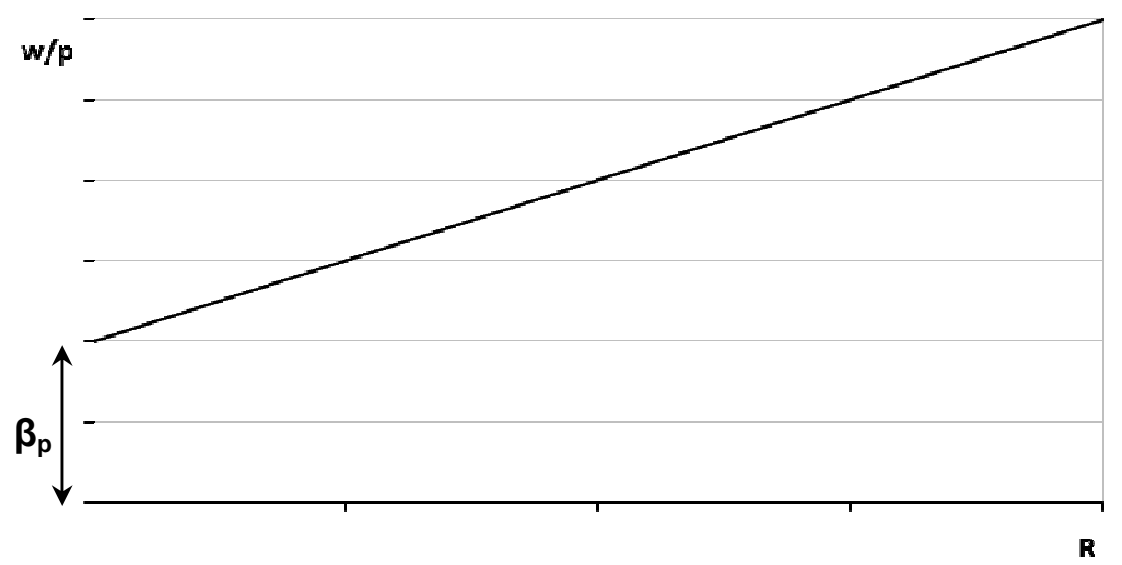

Figure 3: Variation of the spreading diameter as a function of water content of the paste and determination of $\beta_{p}$

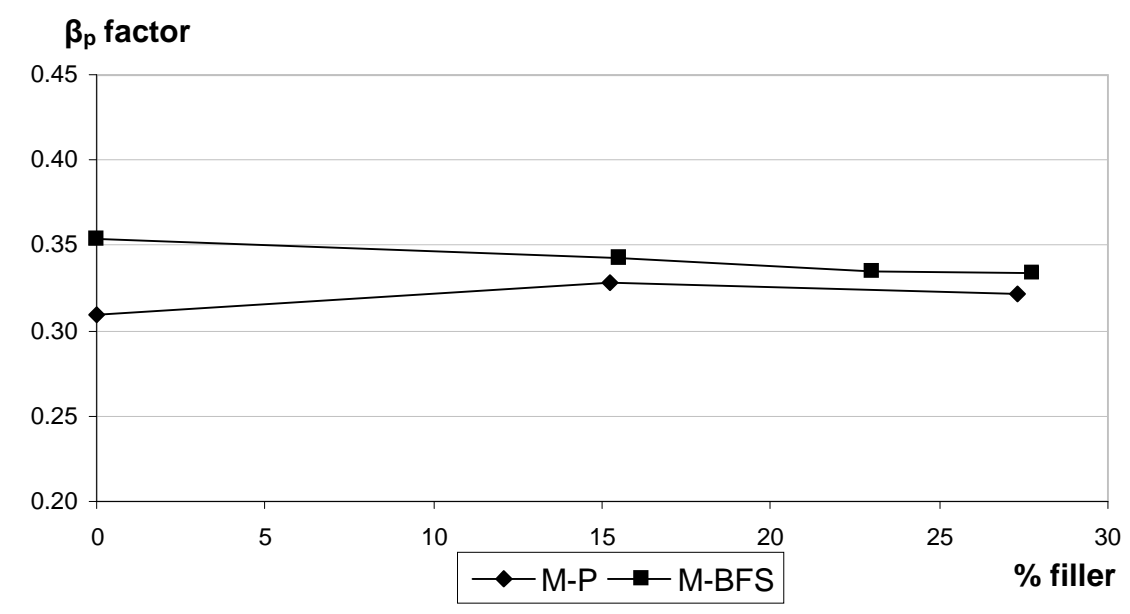

Figure 4: Water demand ( $\beta_{\mathrm{p}}$ factor expressed by mass) for M-P and M-BFS samples 


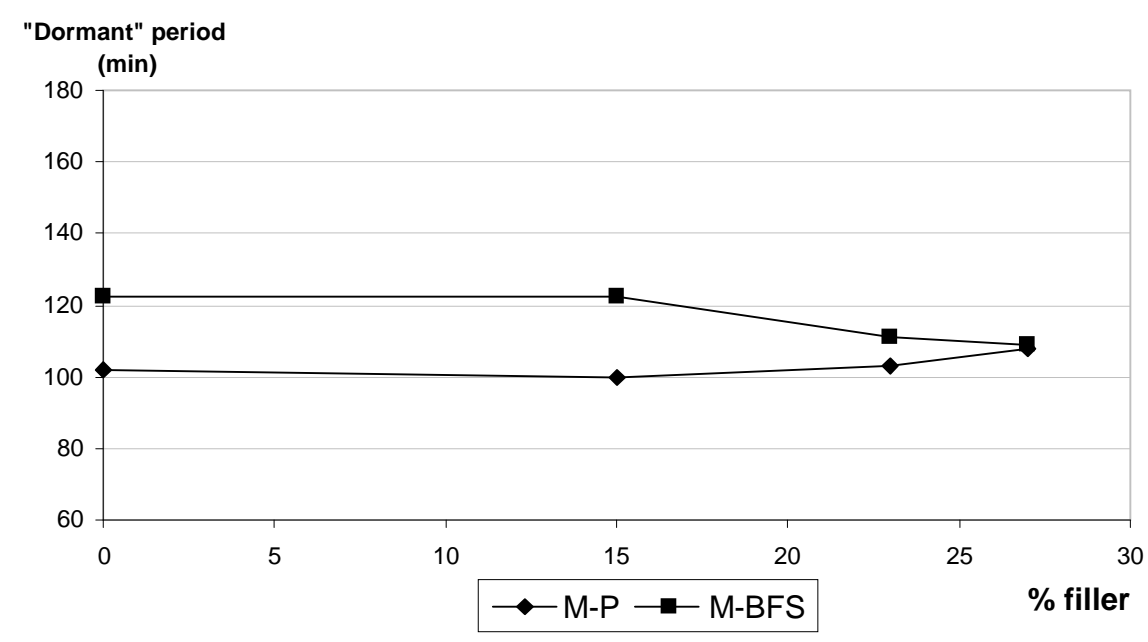

Figure 5: The "dormant" period for M-P and M-BFS samples

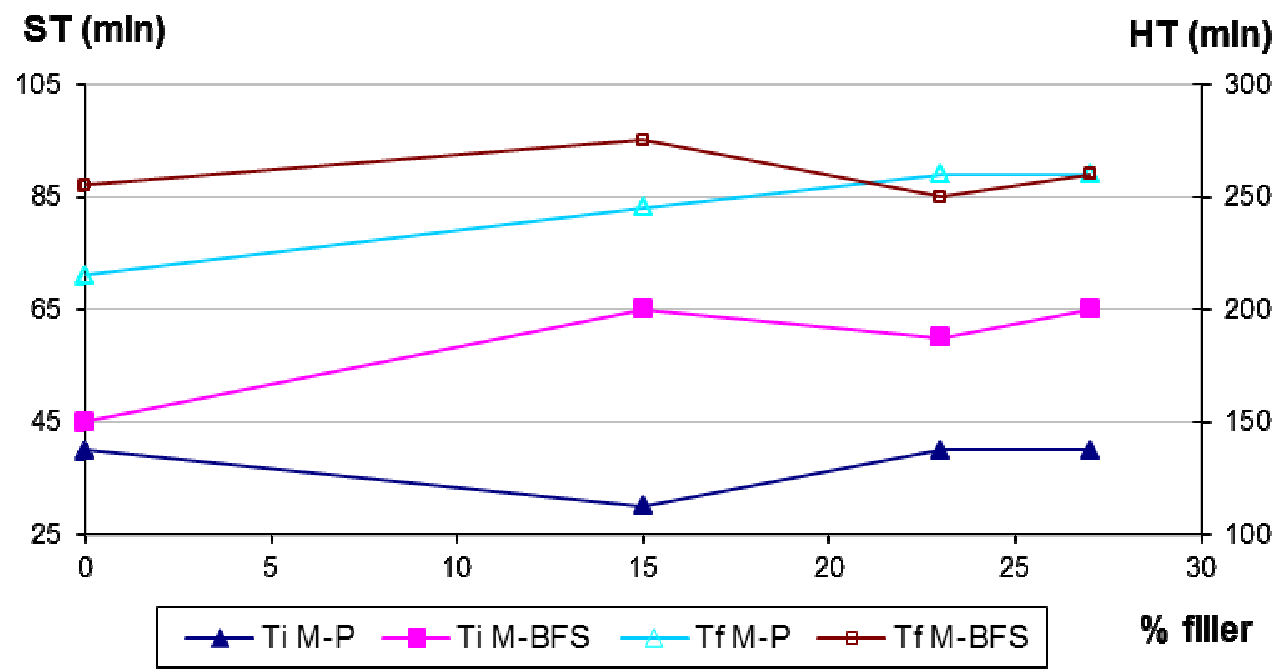

Figure 6: setting (ST) and hardening (HT) times of M-P and M-BFS samples 


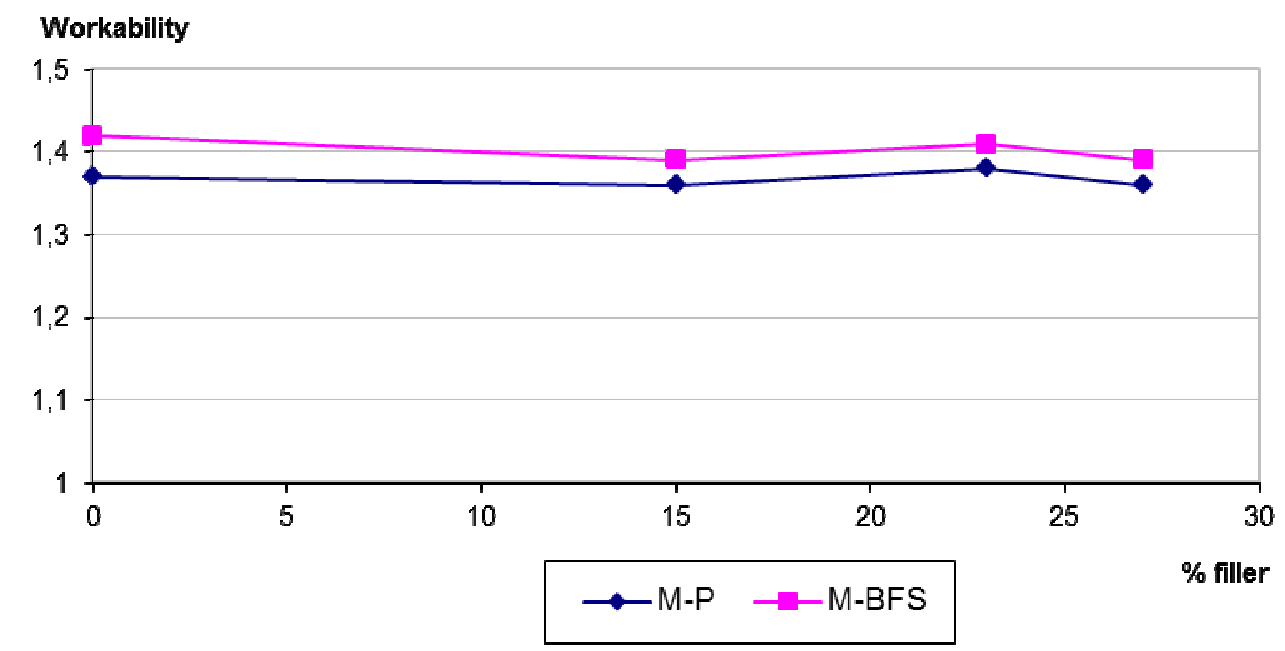

Figure 7: workability (flow test) of M-P and M-BFS samples

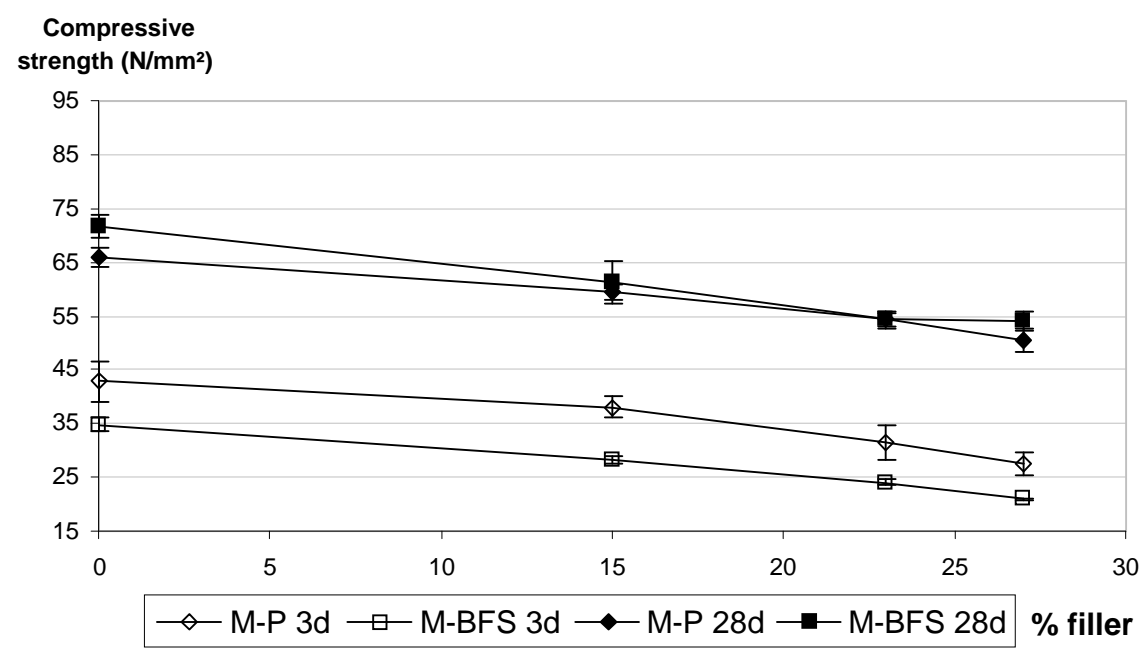

Figure 8: Compressive strength at 3 and 28 days for M-P and M-BFS samples with regard to limestone filler content 


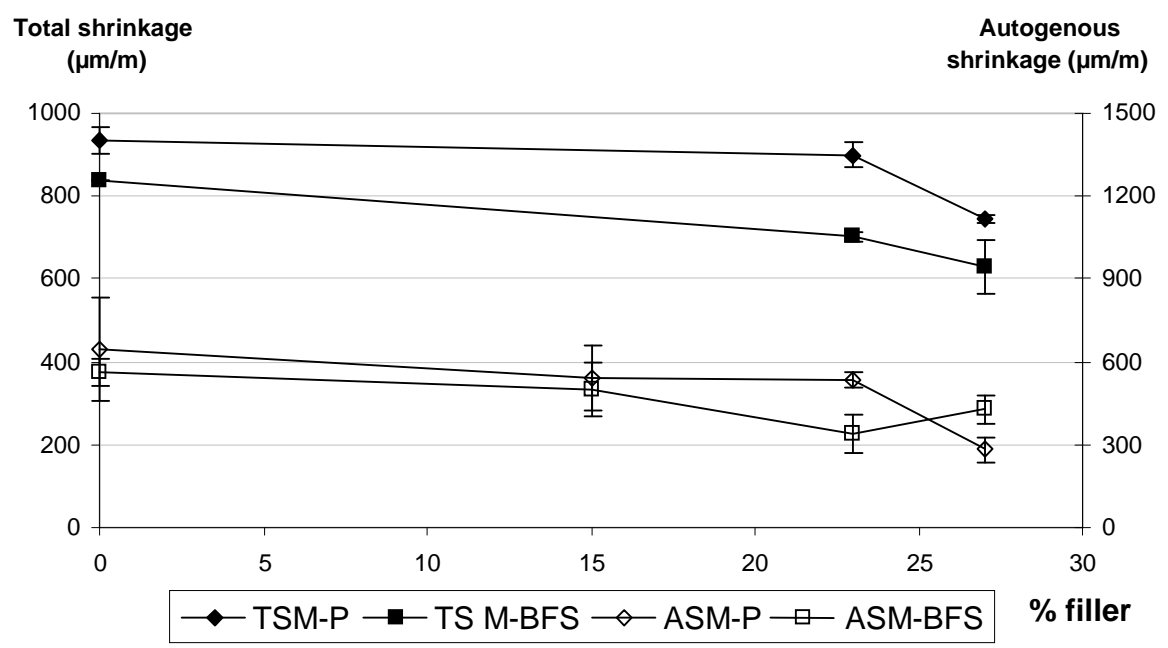

Figure 9: Total (TS) and autogenous (AS) shrinkages after 28 days for M-P and M-BFS samples

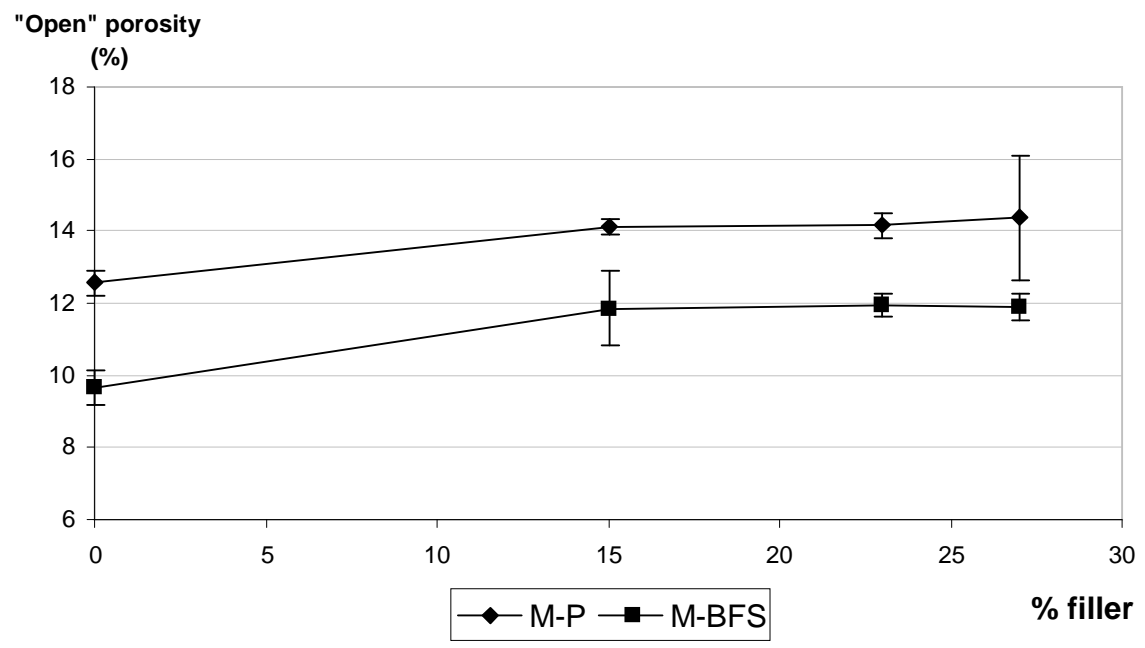

Figure 10: "Open" porosity M-P and M-BFS samples, measured by water absorption 


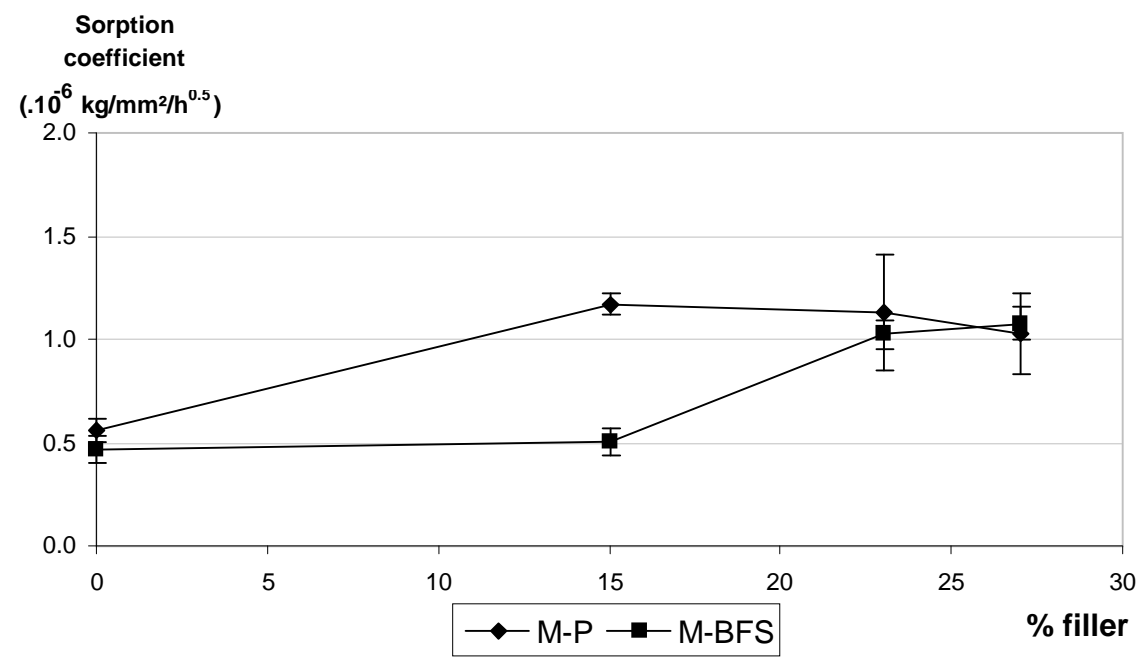

Figure 11: Sorption coefficient for M-P and M-BFS samples

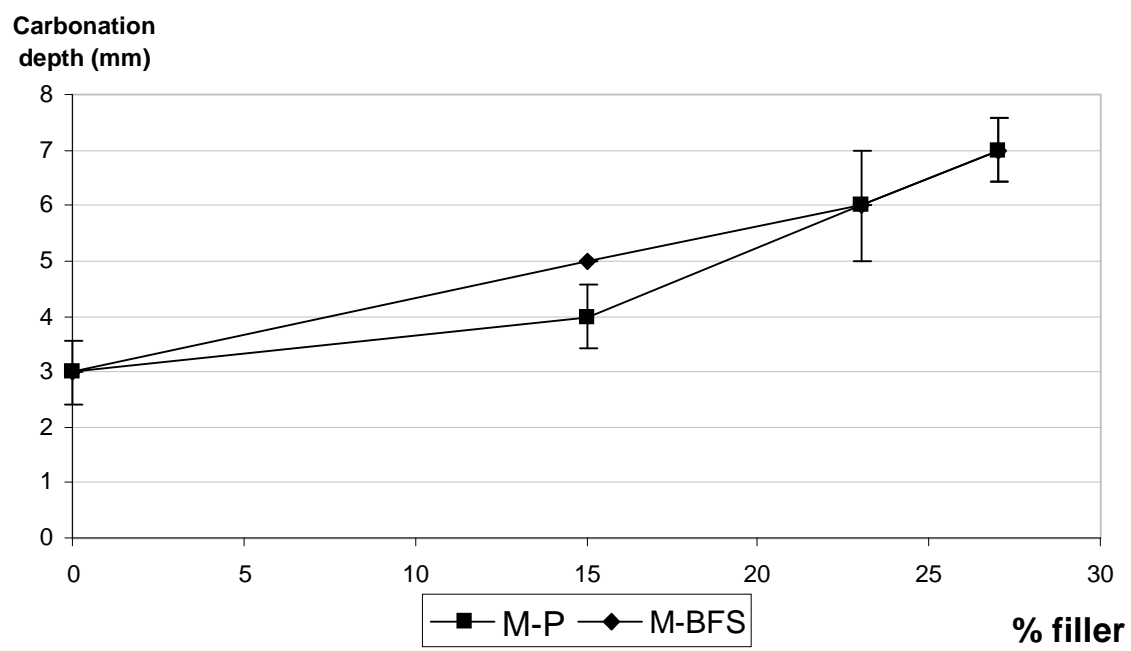

Figure 12: Carbonation depth after 3 months for M-P and M-BFS samples 


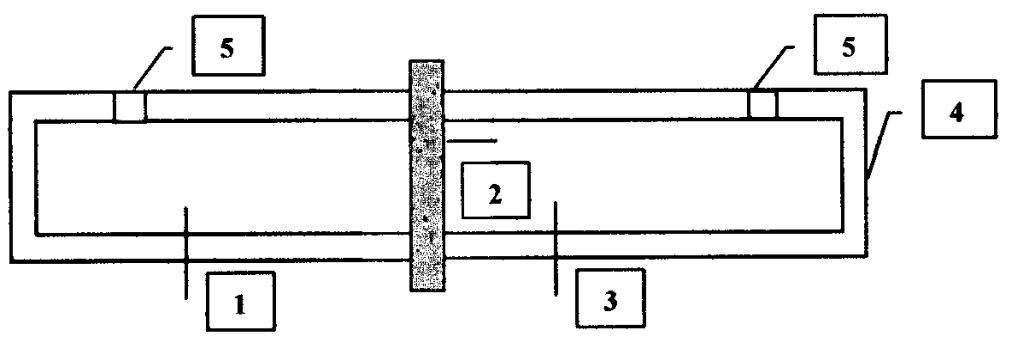

$1=$ saturated $\mathrm{Ca}(\mathrm{OH})_{2}$ solution $+1 \mathrm{M} \mathrm{NaCl}$

$2=$ specimen (paste or mortar)

$3=$ saturated $\mathrm{Ca}(\mathrm{OH})_{2}$ solution

$4=$ container (PMMA)

$5=$ opening for collection of solution samples and fulfilling of cells

Figure 13: Experimental setup of diffusion cell [23]

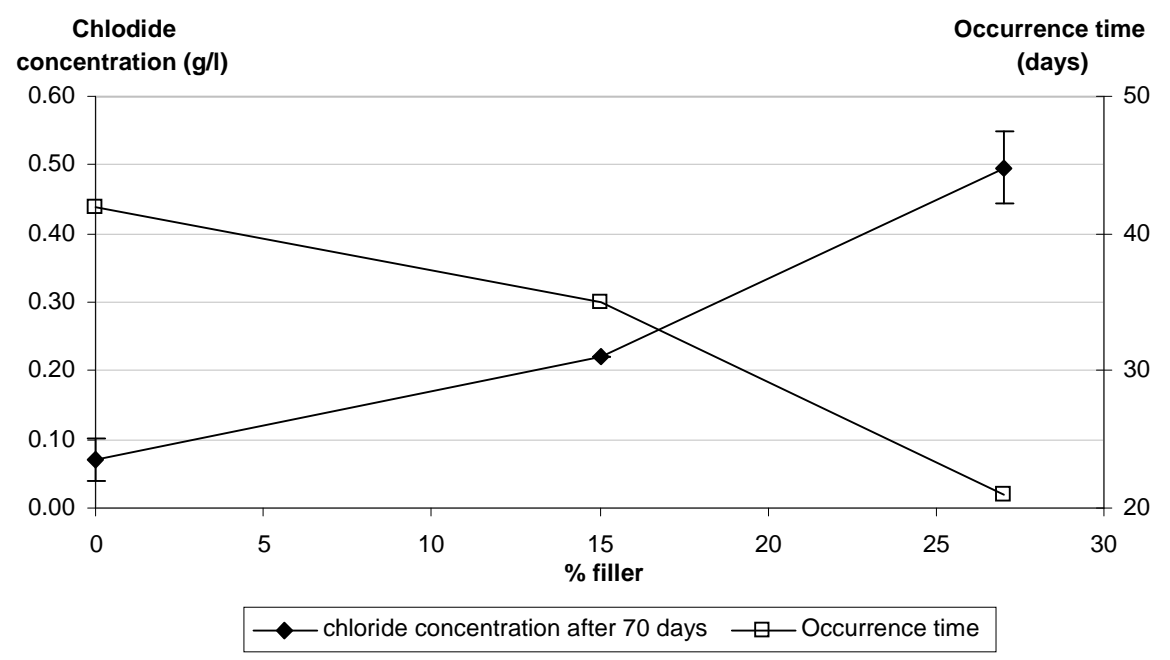

Figure 14: Chloride concentration and occurrence time for M-P samples 


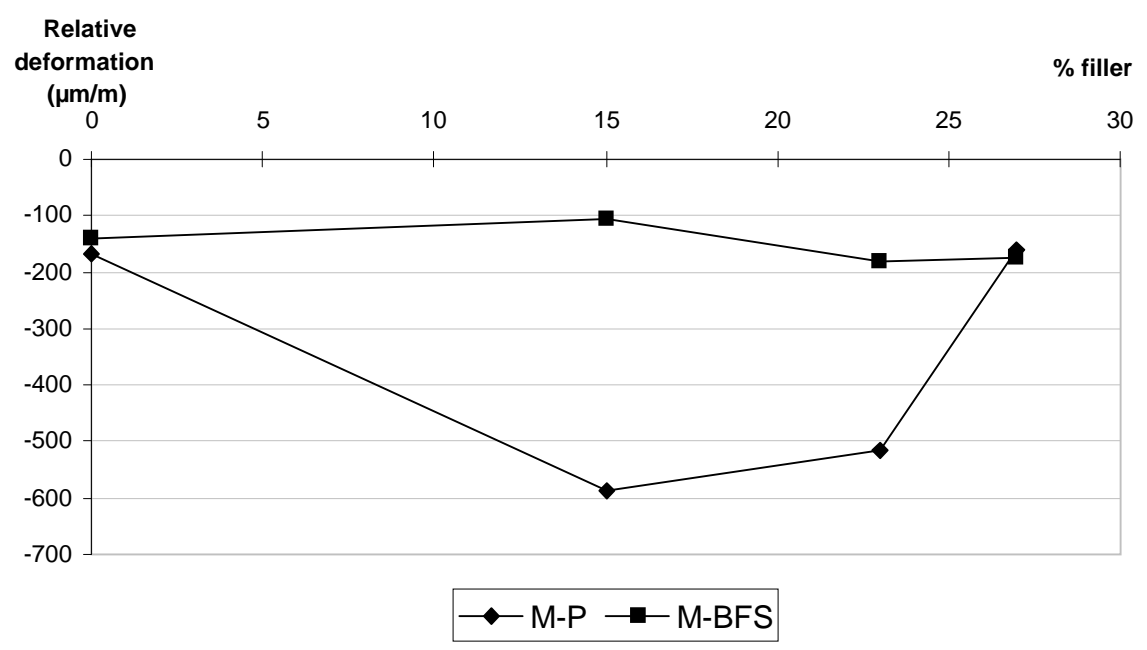

Figure 15: Relative deformation in sulphate solutions for M-P and M-BFS samples after 3 months 